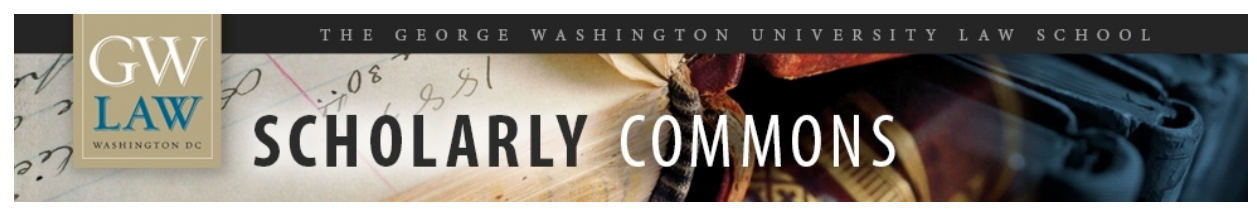

\title{
Pollution Limits and Polluters' Efforts to Comply: The Role of Government Monitoring and Enforcement
}

\author{
Robert L. Glicksman \\ George Washington University Law School, rglicksman@law.gwu.edu \\ Dietrich Earnhart
}

Follow this and additional works at: https://scholarship.law.gwu.edu/faculty_publications

Part of the Law Commons

\section{Recommended Citation}

Robert L. Glicksman \& Dietrich Earnhart, POLLUTION LIMITS AND POLLUTERS' EFFORTS TO COMPLY: THE ROLE OF GOVERNMENT MONITORING AND ENFORCEMENT (Stanford University Press, 2011).

This Article is brought to you for free and open access by the Faculty Scholarship at Scholarly Commons. It has been accepted for inclusion in GW Law Faculty Publications \& Other Works by an authorized administrator of Scholarly Commons. For more information, please contact spagel@law.gwu.edu. 
D. EARNHART \& R. GLICKSMAN, POLLUTION LimitS AND POLLUTERS’ EFFORTS TO COMPLY:

THE ROLE OF GOVERNMENT MONITORING AND ENFORCEMENT

Chapter 1, Page Proof Version

\title{
Material from \\ POLLUTION LIMITS AND POLLUTERS' EFFORTS TO COMPLY: THE ROLE OF GOVERNMENT MONITORING AND ENFORCEMENT
}

\author{
by Dietrich H. Earnhart \& Robert L. Glicksman \\ (C) by Stanford University, all rights reserved (2011). \\ Any reproduction, distribution, or further use of this material, in any way or by any \\ University Press.
} means, is strictly prohibited without the prior written permission of the publisher, Stanford

\section{Chapter 1}

\section{Introduction}

\subsection{The Promise and Pitfalls of the Clean Water Act}

In 1972, Congress adopted one of the nation's landmark environmental laws, the Federal Water Pollution Control Act Amendments, now known as the Clean Water Act. Passage was prompted by concern over the egregious state of the quality of the nation's rivers, lakes, and streams, some of which were so contaminated by industrial chemicals that they caught on fire. Others were befouled with oil from events like the Santa Barbara oil spill in January 1969, which produced images on television news broadcasts of oil slicks and tar-soaked birds and marine mammals. The new law sought to "restore and maintain the chemical, physical, and biological integrity of the Nation's waters" by establishing a goal of eliminating the discharge of pollutants into navigable waters by 1985 .

That lofty goal was obviously not achieved by the target date, and is still little more than a distant and perhaps impossible dream. There is little question, however, that over the nearly four decades since the enactment of the Clean Water Act, enormous progress has been made in cleaning up the nation's waters. The quality of major rivers like the Hudson and the Potomac has improved sufficiently to allow recreational uses that most would not have dared to pursue in the late 1960s and early 1970s. Few would dispute the notion that the Clean Water Act has been an enormously successful pollution abatement initiative.

Yet, as the first decade of the twenty-first century approached an end, and with the fortieth anniversary of the Clean Water on the horizon, trouble was brewing. From many quarters, disturbing reports of failures to enforce the law streamed in. In a lead editorial published late in 2009, the New York Times wrote that "even its staunchest allies agree than the 
D. EARNHART \& R. GLICKSMAN, POLLUTION LIMITS AND POLLUTERS’ EFFORTS TO COMPLY:

THE ROLE OF GOVERNMENT MONITORING AND ENFORCEMENT

Chapter 1, Page Proof Version

act has grown old and fallen well short of its goals, crippled by uneven and sometimes nonexistent enforcement by state and federal agencies. ..." (NY Times, 2009).

The newspaper's concern was triggered by investigative reports from the paper's own reporters. In an expose published in September 2009, the Times reported that more than 500,000 known violations of the Clean Water Act had occurred during the period 2004-2007 by more than 23,000 facilities, according to records submitted by the polluters themselves. Those figures likely underestimated the scale of the problem because some facilities engaged in illegally discharges fail to inform the government of these violations. According to environmental groups, the number of Clean Water Act violations had increased significantly in recent years. The Times reported that that the number of facilities violating the Clean Water Act increased by more than 16 percent between 2004 and 2007. Worse, about sixty percent of the violations qualified as "significant," a term used to identify violations posing the highest public health or environmental risks (Duhigg, 2009).

The occurrence of frequent violations was bad enough news in itself, but that was only part of the disturbing story. According to the Times, fewer than three percent of Clean Water Act violations during the period investigated by the paper resulted in fines or other significant punishments by state officials; moreover, the federal Environmental Protection Agency (EPA) did little to press the states to take their enforcement responsibilities more seriously or to step into the breach created by inadequate state enforcement. State officials blamed the absence of vigorous enforcement despite high rates of regulatory noncompliance on increased workloads and dwindling resources: state enforcement budgets remained essentially flat when adjusted for inflation even though the number of regulated facilities more than doubled in the previous ten years. The Times concluded that state regulators often lacked the ability or training to levy fines large enough to deter polluters. Even though EPA acknowledged the problem, it hesitated to pressure the states to do better, partly because of its reluctance to risk putting stress on its relationships with state enforcement officials and partly because it lacked a consistent national oversight strategy (Duhigg, 2009).

Other contemporaneous accounts were consistent with the Times findings. In testimony given before Congress the month after the Times story appeared, the United States General Accountability Office (GAO) noted that while overall funding for carrying out enforcement activities in EPA's regional offices and in states authorized to issue and enforce Clean Water Act permits states had increased from fiscal years 1997 through 2006, those increases failed to keep pace with inflation and the agencies' growth in enforcement responsibilities. More specifically, funding to EPA regional offices increased from \$288 million in fiscal year 1997 to \$322 million in fiscal year 2006, but declined in real terms by eight percent over that period. The decline in funding was reflected in a decrease in full-time employees in many of EPA's regional offices. Essentially, both EPA and state officials felt overwhelmed by increased responsibilities and declining resources to meet them (GAO, 2009). The GAO concluded that "our work over the past 9 years has shown that the Clean Water Act has significantly increased EPA's and the states' enforcement responsibilities, available resources have not kept pace with these increased needs, and actions are needed to further strengthen the enforcement program" (GAO, 2009, p.

Ch $1-2$ 
D. EARNHART \& R. GLICKSMAN, POLLUTION LIMITS AND POLLUTERS’ EFFORTS TO COMPLY:

THE ROLE OF GOVERNMENT MONITORING AND ENFORCEMENT

Chapter 1, Page Proof Version

14). Among the specific consequences of the collapse of effective enforcement described by the GAO was a decline in the value of injunctive relief, which for purposes of its report the GAO defined as the monetary value of future investments necessary for an alleged violator to come into compliance. Reviewing EPA's assessed penalties from fiscal years 1998 to 2007, the GAO found that total inflation-adjusted penalties declined from approximately $\$ 240.6$ million in fiscal year 1998 to only $\$ 137.7$ million in 2007 (GAO, 2009).

In the face of these troubling depictions of the state of Clean Water Act compliance and enforcement, EPA released a Clean Water Act Enforcement Action Plan in October 2009 (EPA, 2009). The Plan concedes forthrightly that Clean Water Act "violations are still too widespread, and enforcement too uneven" (EPA, 2009, p. i). It finds that "[m]any of the nation's waters are not meeting water quality standards, and the threat to drinking water sources is growing" (EPA, 2009 , p. i). Although EPA found that some states had strong water quality protection and enforcement programs, compliance and enforcement vigor were uneven (EPA, 2009). Like the Times, EPA found unacceptably high rates of significant noncompliance - about 24 percent among the nation's largest direct discharge facilities (EPA, 2009). EPA data reveal even higher rates (about 45 percent) of serious noncompliance (which the GAO equated with EPA's concept of "significant noncompliance") at smaller facilities that submit discharge monitoring reports (EPA, 2009). Yet, according to EPA (2009), the states reported taking enforcement action against fewer than six percent of these smaller facilities.

The absence of consistent enforcement by EPA and the states created "an unlevel playing field" for businesses complying with the law and for citizens seeking protection against the health and environmental risks posed by unlawful water pollution discharges. The Action Plan pronounced that:

[e]ffective enforcement programs create incentives for compliance by penalizing those who do not follow the law. They establish a level playing field between those members of the regulated community who comply and those who do not. Enforcement ensures fair treatment - companies that compete against each other should not face wide disparities in treatment across the country, such as mandatory minimum penalties for a violation in one state and no enforcement in another. Ultimately, enforcement is critical to ensure that the public receives the services and protections promised by our laws. Unfortunately, data shows us that we are not getting the compliance envisioned by our laws to protect clean water" (EPA, 2009, p. 6).

EPA's assessment of the state of Clean Water Act compliance and enforcement led it to conclude that new approaches were needed to revamp its enforcement program so that EPA and the states would focus their enforcement efforts on the Clean Water Act violations that posed the biggest threats to water quality and public health, including a reinvigoration of both civil and criminal enforcement against traditional end-of-pipe pollution. Testifying before Congress at the same hearings at which the GAO appeared to announce the formulation of the new Action Plan, EPA Administrator Lisa Jackson proclaimed that " $[t]$ he time is long overdue for E.P.A. to reexamine its approach to Clean Water Act enforcement," and that EPA's goal was to "develop

Ch $1-3$ 
D. EARNHART \& R. GLICKSMAN, POLLUTION LimitS AND POLLUTERS’ EFFORTS TO COMPLY:

THE ROLE OF GOVERNMENT MONITORING AND ENFORCEMENT

Chapter 1, Page Proof Version

more innovative approaches to target enforcement to the most serious violations and the most significant sources" (Duhigg, 2009).

\subsection{Contribution of Present Study}

This book seeks to provide insights into the impacts of Clean Water Act enforcement on both performance and behavior by facilities regulated under the statute. In doing so, its goals include providing information to EPA and the states responsible for implementing and enforcing the Clean Water Act. We anticipate that the information may assist them in fashioning the kind of innovative and effective enforcement programs that EPA Administrator Jackson has identified as necessary for providing the fair treatment of regulated facilities, effective public health and environmental protection, and achievement of the goals and promise that the Clean Water Act staked out in 1972.

The analysis in this book is based on information on Clean Water Act enforcement that relates to the same period of time analyzed by the GAO testimony and EPA Clean Water Act Enforcement Plan released in October 2009. In particular, the data we analyze here measure facility discharges and enforcement actions taken during the period 1999 to 2003 . The study focuses on discharges by and enforcement actions taken, along with inspections conducted, against discharging facilities in the chemical industry, one of the most significant industries regulated by the Clean Water Act and one that on occasion EPA has designated as a priority industrial sector.

The book examines several broad research questions. These include what the variations are in the discharge limits that apply to discharging facilities with wastewater permits, what actions discharging facilities are taking to comply with their discharge limits, what outcomes (in terms of discharges and compliance) result from various forms of environmental behavior, and what steps federal and state regulators are taking to induce compliance with discharge limits. We seek to ascertain whether different forms of enforcement actions and inspections help to induce better environmental behavior or better environmental performance by regulated facilities. We also assess how discharge limits affect environmental behavior and performance and how environmental behavior affects environmental performance.

Our goal in analyzing these issues with respect to facilities in the chemical industry is to provide information that may be useful to environmental policymakers in both the federal and state governments in designing regulatory and enforcement programs that induce improvements in environmental performance and desirable changes in behavior by regulated facilities. By studying the impact of past regulatory activity — crafting discharge limits for polluting facilities in the chemical industry and pursuing enforcement actions against facilities alleged to have violated their regulatory obligations under the Clean Water Act, we should be able to provide useful information so that policymakers may be able to maximize the degree to which regulatory expenditures create the greatest degree of improvements in environmental compliance. 


\section{THE ROLE OF GOVERNMENT MONITORING AND ENFORCEMENT}

\section{Chapter 1, Page Proof Version}

Although other empirical studies cited throughout this book assess the impacts of certain regulatory decisions on environmental performance and behavior, we are not aware of any empirical study that engages in the kind of sweeping evaluation of a broad range of regulatory actions on an important polluting industry that we undertake in this book. Further, the fact that the data surveyed and analyzed here derive from the very period that both EPA and the GAO have pointed to as evidence of the failure of past federal and state enforcement approaches affords us a unique opportunity to determine the extent to which particular kinds of regulatory and enforcement efforts have succeeded or contributed to past enforcement failures.

\subsection{The Clean Water Act in a Nutshell}

The Clean Water Act announces as its ultimate goal the elimination of all discharges of pollution to the nation's waterways and as an interim goal the achievement of fishable, swimmable waters. The principal legal tool for achieving these goals is a provision that makes it unlawful to discharge pollutants into waters of the United States without a permit. The Clean Water Act creates two permit programs, only one of which is relevant to this book. That program is the National Pollutant Discharge Elimination System or NPDES permit program. This program is administered by states that EPA has authorized to issue individual discharge permits to point sources of pollution, or by EPA itself in states that have not been so authorized. Point sources are those that discharge pollutants through discrete conveyances, such as pipes, rather than through diffuse runoff.

The Clean Water Act requires that a permit impose discharge limits on regulated sources. These limits restrict the quantity or concentration of pollutants that sources may discharge into the nation's waterways. EPA issues regulations that contain effluent limitation guidelines that apply to entire industrial categories of sources. These limitations are based on the degree of pollution reduction that EPA determines is achievable through the use of technology that is available to the industry concerned. Permit issuing agencies use the regulatory limitations as the starting point for determining the discharge limits to impose on individual sources applying for a wastewater discharge permit. Those discharge limits may differ from the regulatory limitations for any number of reasons (which Chapter 4 describes in more detail). The Clean Water Act allows the states to impose discharge limits that are more stringent than those demanded by EPA. If a state environmental agency decides to exercise that authority, the discharge limit it imposes on a source in its NPDES permit may be more stringent than the limitations adopted in EPA's effluent limitation guidelines for the relevant industry.

Another reason that the individual discharge limits for a particular point source may differ from the regulatory limitations relates to water quality standards adopted by the states. The Clean Water Act requires that every state adopt and periodically revise water quality standards designed to protect the public health and welfare, enhance water quality, and serve the Clean Water Act's purposes. If a state determines that the quality of a particular body of water, such as a stream or lake, is not adequate to meet the applicable water quality standard, it is responsible for devising strategies for reducing pollutant concentrations in that waterway to the 


\section{THE ROLE OF GOVERNMENT MONITORING AND ENFORCEMENT}

\section{Chapter 1, Page Proof Version}

extent needed to bring the waterway into compliance with the water quality standard. One way to do so is to impose discharge limits on point sources in NPDES permits that are more stringent than those that appear in EPA's effluent limitations guidelines.

The Clean Water Act also establishes an extensive enforcement program. The statute authorizes EPA to establish reporting requirements on point source discharges, inspect regulated facilities, and initiate appropriate enforcement action against sources alleged to be discharging without a permit or to be in violation of their permits or other regulatory obligations. Although the statute allows the federal government to bring criminal charges against violators, the focus of this book is on the Clean Water Act's civil enforcement provisions. The statute authorizes EPA to pursue informal enforcement actions, impose administrative penalties and to issue civil administrative orders that mandate actions needed to bring regulated sources into compliance. Alternatively, EPA may bring suit in federal court seeking the same kinds of relief. In some cases, the courts also have been willing to require violators to pursue supplemental environmental projects to mitigate or offset the environmental harms the actions have caused. Although both proceedings in court to impose monetary penalties or injunctive relief and administrative proceedings seeking the same remedies are both properly characterized as civil (as opposed to criminal) proceedings, we use the term "civil" in this book exclusively in connection with judicial proceedings. We refer to enforcement actions resolved by EPA or state agency officials rather than by judges as administrative proceedings.

The Clean Water Act also envisions enforcement by the states. Indeed, one of the conditions that a state must meet before it is eligible to administer the NPDES permit program is a demonstration to EPA that it has adequate legal authority and resources to enforce the law. The manner in which states are allowed to enforce the Clean Water Act permits they issue differs in accordance with the laws of each state. Generally, however, the states have the authority to demand the same kinds of reports that EPA requires of regulated sources, inspect those sources, and impose (or seek judicial imposition of) civil penalties and injunctive orders on violators. EPA retains the power to enforce the Clean Water Act even in the states that it has authorized to administer and enforce the NPDES permit program. This book examines both permits issued by and inspections conducted by state agencies but not enforcement actions taken by state agencies. here.

Chapters 4 and 7 describe more fully the provisions of the Clean Water Act summarized

\subsection{Historical Data}

This last section provides data on the amounts of pollutants discharged into the nation's waters, the compliance status of regulated facilities, and the number of enforcement actions and inspections taken by EPA and the states during the period covered by our study (1999-2003). These figures provide background for the analysis of the questions we pose throughout the book concerning discharge limits, environmental behavior, environmental performance, government interventions, and the relationships among these variables. 
D. EARNHART \& R. GLICKSMAN, POLLUTION LimitS AND POLLUTERS’ EFFORTS TO COMPLY:

THE ROLE OF GOVERNMENT MONITORING AND ENFORCEMENT

Chapter 1, Page Proof Version

\subsubsection{Wastewater Discharges}

The chemical industry discharges significant amounts of pollutants into the nation's waters, making its performance and behavior important to an assessment of the impact of Clean Water Act enforcement. As Table 1.1 illustrates, in the years covered by our study (1999-2003), the chemical and allied products sector discharged between 44.5 and 77.1 million pounds of pollutants into the nation's surface waters. The amount discharged declined each year (data for 2002 are not available), as did chemical industry discharges as a percentage of the total amount discharged by all industrial sectors. Nevertheless, the percentage of the total amount discharged by all industrial sectors that was discharged by the chemical and allied product sector discharged remained substantial — between 20.0 and 29.8 percent.

[Insert Table 1.1]

\subsubsection{Government Interventions: Inspections and Enforcement Actions}

Chapter 7 below addresses the degree to which EPA and the states engaged in inspections of facilities in the chemical industry with NPDES permits and took enforcement actions against those facilities. Chapters 8 and 9 analyze the impact of these inspections and enforcement actions (which we refer to collectively as "government interventions") on environmental behavior and environmental performance in this industrial sector. To provide a backdrop for this analysis, we provide here a depiction of the degree to which EPA engaged in government interventions across all industrial sectors during the period covered by our study (1999 to 2003). Table 1.2 provides the dollar values of different forms of formal enforcement action, both civil and criminal (although this book focuses exclusively on civil enforcement). The data indicate that the dollar value of civil judicial penalties assessed across all industrial sectors varies significantly during this period, ranging from about $\$ 7$ million in 1999 to about $\$ 59$ million in 2003. The range of dollar values for administrative civil penalties assessed during this period is much smaller (between about $\$ 5$ to $\$ 7$ million dollars), and the dollar amounts assessed are significantly less than the amounts assessed in judicial proceedings in every year except 1999. The dollar value of combined injunctive relief provided in both civil judicial and administrative proceedings far outstrips the value of either judicial or administrative civil penalties assessed in every year for which figures are available, although the dollar value of injunctive relief varies widely over the time period covered by our study. For the years for which data are available, the dollar value of judicial injunctive relief outstrips the value of administrative injunctive relief, and is far greater than the value of either judicially or administratively assessed civil penalties for the same year. The dollar value of supplemental environmental projects (SEPs) pales in comparison with the dollar value of either judicial or administrative injunctive relief, but is fairly comparable to the value of civil judicial penalties assessed for most of the years covered by our study.

[Insert Table 1.2]

Table 1.3 provides information about the number of inspections (by both EPA and the states) against both major and minor facilities with NPDES permits and various kinds of 


\section{THE ROLE OF GOVERNMENT MONITORING AND ENFORCEMENT}

\section{Chapter 1, Page Proof Version}

informal and formal enforcement actions taken by EPA during the period covered by our study. Although data are not available for every year we studied, the figures show that the states were far more active in inspecting facilities with NPDES permits than EPA was. This result is not surprising given that some forty-five states have received permission from EPA to administer the NPDES permit program (i.e., have "primacy" in NPDES permit enforcement, with EPA retaining a backup role). The data show a marked and consistent decline in the number of informal actions and notices of violation issued over the period we studied. The number of administrative compliance orders issued and administrative penalty order complaints remains fairly constant over time, by contrast. Finally, EPA entered into relatively few civil judicial settlements during the entire five-year period we studied.

\section{[Insert Table 1.3]}

The final table provides data concerning informal and formal enforcement actions taken by EPA's regional offices between 1999 and 2003. Perhaps the starkest figure to emerge from these data is the wide divergence among the regions. Regions 1 and 10 were relatively inactive during the period we studied, whereas Regions 2 and 6 were active in pursuing both civil penalties and SEPs.

[Insert Table 1.4] 
D. EARnhart \& R. Glicksman, POLlution Limits AND POLluters’ EFFORTs to COMPly:

THE ROLE OF GOVERNMENT MONITORING AND ENFORCEMENT

Chapter 1, Page Proof Version

Chapter 1 Tables

Table 1.1

Surface Water Discharges: 1999-2003 ${ }^{a, b}$

\begin{tabular}{|r|r|r|r|}
\hline Year & $\begin{array}{r}\text { Surface Water } \\
\text { Discharges - Total } \\
\text { (millions of pounds) }\end{array}$ & $\begin{array}{r}\text { Surface Water } \\
\text { Discharges }- \\
\text { Chemical and Allied } \\
\text { Products Sector } \\
\text { (millions of pounds) }\end{array}$ & $\begin{array}{r}\text { Percentage of Total } \\
\text { Discharges by } \\
\text { Chemical and Allied } \\
\text { Products Sector }\end{array}$ \\
\hline 1999 & 258.9 & 77.1 & 29.8 \\
\hline 2000 & 260.9 & 68.7 & 26.3 \\
\hline 2001 & 220.8 & 57.6 & 26.1 \\
\hline 2002 & $\mathrm{n} / \mathrm{a}$ & $\mathrm{n} / \mathrm{a}$ & $\mathrm{n} / \mathrm{a}$ \\
\hline 2003 & 222.6 & 44.5 & 20.0 \\
\hline
\end{tabular}

a Source (1): Statistical Abstract of the United States 2001, Table 363;

Source (2): Statistical Abstract of the United States 2002, Table 355;

Source (3): Statistical Abstract of the United States 2004-2005, Table 367;

Source (4): Statistical Abstract of the United States 2006, Table 367.

${ }^{b}$ Based on reports filed under $\S 313$ of the Emergency Planning and Community Right-to-Know Act, facilities within SIC Codes 20 through 39 with 10 or more full-time employees

Ch $1-9$ 
D. EARnhART \& R. GliCKSMAn, POLLUtion Limits AND POLLUTERS' EFFORTS TO COMPLY:

THE ROLE OF GOVERNMENT MONITORING AND ENFORCEMENT

Chapter 1, Page Proof Version

Table 1.2

Clean Water Act Enforcement Activity, FY 1999-2003 ${ }^{\text {a }}$

\begin{tabular}{|c|c|c|c|c|c|c|c|}
\hline $\begin{array}{l}\text { Fiscal } \\
\text { Year }\end{array}$ & $\begin{array}{l}\text { Criminal } \\
\text { Penalties } \\
\text { Assessed }\end{array}$ & $\begin{array}{l}\text { Civil Judicial } \\
\text { Penalties } \\
\text { Assessed }\end{array}$ & $\begin{array}{l}\text { Administrative } \\
\text { Penalties } \\
\text { Assessed }\end{array}$ & $\begin{array}{l}\text { Dollar Value of } \\
\text { Injunctive } \\
\text { Relief }\end{array}$ & $\begin{array}{l}\text { Dollar Value of } \\
\text { Judicial Injunctive } \\
\text { Relief }\end{array}$ & $\begin{array}{l}\text { Dollar Value of } \\
\text { Administrative } \\
\text { Injunctive Relief }\end{array}$ & $\begin{array}{l}\text { Dollar Value of } \\
\text { SEPs }\end{array}$ \\
\hline 1999 & $26,344.626$ & $7,416,728$ & $5,200,575$ & $577,486,331$ & not available & not available & $8,620,321$ \\
\hline 2000 & $49,901,801$ & $21,579,394$ & $5,403,201$ & $156,813,072$ & not available & not available & $10,857,998$ \\
\hline 2001 & $46,471,389$ & $17,984,220$ & $5,554,194^{b}$ & $168,587,320^{c}$ & $118,757,092$ & $60,925,238$ & $3,390,528$ \\
\hline 2002 & $35,884,399$ & $16,951,009^{d}$ & $4,940,169$ & $2,305,638,458$ & $1,788,732,451$ & $813,784,601$ & $13,078,678$ \\
\hline 2003 & not available & $59,829,967$ & $6,816.642$ & not available & not available & not available & $9,344,514$ \\
\hline
\end{tabular}

a Source (1): FY 1996 Enforcement and Compliance Assurance Accomplishments Report, at A-2, available at

http://www.epa.gov/compliance/resources/reports/accomplishments/oeca/fy96accomplishment.pdf;

Source (2): EPA, Enforcement and Compliance Assurance Accomplishments Report FY 1997, at A-2, available at

http://www.epa.gov/compliance/resources/reports/accomplishments/oeca/fy97accomplishment.pdf;

Source (3): EPA, Enforcement and Compliance Assurance: FY98 Accomplishments Report 93, available at http://www.epa.gov/compliance/resources/reports/accomplishments/oeca/fy98accomplishment.pdf;

Source (4): EPA, Annual Report on Enforcement and Compliance Assurance Accomplishments in 1999, at B-1; Source (5): Protecting the Public and the Environment Through Innovative Approaches: Fiscal Year 2001 Enforcement and Compliance Assurance Accomplishments Report 72, EPA300-R-02-010;

Source (6): Environmental Results through Smart Enforcement: Fiscal Year 2002 Enforcement and Compliance Assurance Accomplishments Report 59, EPA300-R-03-002;

Ch $1-10$ 
D. EARnhart \& R. Glicksman, POllution Limits And POlluters’ EFFORTs to COMPly:

THE ROLE OF GOVERNMENT MONITORING AND ENFORCEMENT

\section{Chapter 1, Page Proof Version}

Source (7): FY 2000 - FY 2008: Administrative and Civil Judicial Penalties Assessed, available at http://www.epa.gov/compliance/resources/reports/nets/nets-f3-adminandjudpen.pdf;

Source (8): FY 1999 - FY 2008: Supplemental Environmental Projects (SEPs), available at http://www.epa.gov/compliance/resources/reports/nets/nets-f4-seps.pdf.

b This figure appears as $\$ 5,353,442$ in Dollar Value of FY 2001 EPA Enforcement Actions (by Statute), available at http://www.epa.gov/compliance/resources/reports/endofyear/eoy2001/eoyfy2001\$lawrpt.pdf, reported as of January 23, 2002.

c This figure appears as $\$ 208,587,320$ in FY 2001 Measures of Success Management Report, at ES-3.

d This figure appears as $\$ 8,706,339$ in Dollar Value of FY 2002 EPA Enforcement Actions (by Statute), available at

http://www.epa.gov/compliance/resources/reports/endofyear/eoy2002/mosfy2002dveabystatute.pdf, reported as of December 9, 2002.

Ch $1-11$ 
D. EARnhART \& R. GliCKSMAn, POLLUtion Limits AND POLLUTERS' EFFORTS TO COMPLY:

THE ROLE OF GOVERNMENT MONITORING AND ENFORCEMENT

Chapter 1, Page Proof Version

Table 1.3

NPDES Enforcement Activity, FY 1999-2003 ${ }^{\text {a }}$

\begin{tabular}{|c|c|c|c|c|c|c|c|c|c|}
\hline \multirow[t]{2}{*}{$\begin{array}{l}\text { Fiscal } \\
\text { Year }\end{array}$} & \multicolumn{2}{|c|}{$\begin{array}{l}\text { EPA Regional } \\
\text { Inspections }\end{array}$} & \multicolumn{2}{|c|}{$\begin{array}{l}\text { State } \\
\text { Inspections }\end{array}$} & \multirow{2}{*}{$\begin{array}{l}\text { Informal } \\
\text { Actions/ } \\
\text { Notices } \\
\text { of } \\
\text { Violation }\end{array}$} & \multirow{2}{*}{$\begin{array}{l}\text { EPA Adm've } \\
\text { Compliance } \\
\text { Orders } \\
\text { Issued }\end{array}$} & \multirow{2}{*}{$\begin{array}{l}\text { EPA } \\
\text { Adm've } \\
\text { Penalty } \\
\text { Order } \\
\text { Complaints }\end{array}$} & \multirow{2}{*}{$\begin{array}{l}\text { EPA } \\
\text { Adm've } \\
\text { Penalty } \\
\text { Settle- } \\
\text { ments }\end{array}$} & \multirow{2}{*}{$\begin{array}{l}\text { EPA } \\
\text { Civil } \\
\text { Judicial } \\
\text { Settle- } \\
\text { ments }\end{array}$} \\
\hline & $\begin{array}{l}\text { NPDES } \\
\text { Majors }\end{array}$ & $\begin{array}{l}\text { NPDES } \\
\text { Minors }\end{array}$ & $\begin{array}{l}\text { NPDES } \\
\text { Majors }\end{array}$ & $\begin{array}{l}\text { NPDES } \\
\text { Minors }\end{array}$ & & & & & \\
\hline 1999 & 965 & 949 & $\mathrm{n} / \mathrm{a}$ & $\mathrm{n} / \mathrm{a}$ & 2080 & 549 & 136 & 186 & 16 \\
\hline 2000 & 1141 & 640 & 9830 & $\begin{array}{r}29,58 \\
5\end{array}$ & 1062 & 596 & 295 & 291 & 12 \\
\hline 2001 & 876 & 758 & 8907 & $\begin{array}{r}27,06 \\
4\end{array}$ & 565 & 367 & 192 & 210 & 24 \\
\hline 2002 & 1044 & 871 & $\mathrm{n} / \mathrm{a}$ & $\mathrm{n} / \mathrm{a}$ & 455 & 490 & 155 & 131 & 33 \\
\hline 2003 & 1221 & 595 & $\mathrm{n} / \mathrm{a}$ & $\mathrm{n} / \mathrm{a}$ & $\mathrm{n} / \mathrm{a}$ & 558 & 208 & 172 & 19 \\
\hline
\end{tabular}

a Source (1): EPA, Annual Report on Enforcement and Compliance Assurance Accomplishments in 1999, at B-2 to B-5;

Source (2): Protecting the Public and the Environment Through Innovative Approaches, Fiscal Year 2001, Enforcement and Compliance Assurance Accomplishments, at 66-69, 100;

Source (3): FY 1994 - FY 2008 Federal Inspection/Evaluation Trends, available at http://www.epa.gov/compliance/resources/reports/nets/nets-g2-inspectionslongterm.pdf;

Source (4): National Enforcement Trends, available at

http://www.epa.gov/compliance/resources/reports/nets/nets-e1-apocomplaints.pdf, at E-1b, E-4b, E-5b, E-7b;

Source (5): FY 2001 Measures of Success Management Report, at C-3.

Ch $1-12$ 
D. EARnhART \& R. GliCKSMAn, POLLUtion Limits AND POLLUTERS' EFFORTS TO COMPLY:

THE ROLE OF GOVERNMENT MONITORING AND ENFORCEMENT

Chapter 1, Page Proof Version

Table 1.4

Regional Enforcement, FY $2001^{\text {a }}$

\begin{tabular}{|l|r|r|r|r|r|r|r|r|r|r|}
\hline & Reg 1 & Reg 2 & Reg 3 & Reg 4 & Reg 5 & Reg 6 & Reg 7 & Reg 8 & Reg 9 & Reg 10 \\
\hline \hline Notices of Violation & 0 & 20 & 0 & 48 & 1 & 411 & 0 & 8 & 0 & 77 \\
\hline $\begin{array}{l}\text { Civil Judicial Penalties } \\
\text { Assessed (\$ 000s) }\end{array}$ & 0 & 758.7 & 1136.7 & 1319.4 & 1002.1 & $14,330.6$ & 6080 & 1127.2 & 469.4 & 15.2 \\
\hline $\begin{array}{l}\text { Civil Admin. Penalties } \\
\text { Assessed (\$ 000s) }\end{array}$ & 628.7 & 1472.6 & 645.7 & 252.7 & 492.1 & 1026.5 & 172.3 & 356.7 & 292.4 & 419.5 \\
\hline $\begin{array}{l}\text { \# of Cases with SEPs } \\
\text { Cost to Implement SEPs (\$ } \\
\text { 000s) }\end{array}$ & $1,310.8$ & 596.6 & 140.3 & 0 & 466.8 & 901.1 & 244.8 & 64.4 & 365.4 & 33.0 \\
\hline \hline
\end{tabular}

a Source: FY 2001 Measures of Success Management Report, at C-3, C-12, 38. The figures in this table for Notices of Violation are specific to the Clean Water Act's National Pollutant Discharge Elimination System permit program. The figures for all other rows are general to the Clean Water Act as a whole.

Ch $1-13$ 